\title{
SURINAAMSCHE MUSKIETEN
}

\author{
C. Bonne en J. Bonne-Wepster; M o s- \\ quitoes of Surinam, a study in \\ neotropical mosquitoes. Amst. \\ De Bussy, 1925.
}

Met tropische muggen heb ik voeling gehad een halve eeuw geleden; tusschen de 400 en 500 tot de Diptera behoorende exemplaren heeft de Sumatra-expeditie medegebracht, die als 122 soorten konden worden ingedeeld. Van der Wulp, de dipteroloog van dien tijd, die de collectie beschreef en van wiens hand ook de prachtig geteekende platen zijn, vond 44 nieuwe soorten en kon er 78 uit reeds bestaande beschrijvingen determineeren; een paar soorten gaven hem aanleiding tot het vormen van nieuwe genera. Men moet, bij de beoordeeling van deze cijfers, wel in het oog houden, dat vele muggen en vliegen teer goedje zijn, en dat de groote Tupuliden met hun onnoodig lange pooten lastig zijn in de behandeling, ook na hun dood. Van der Wulp, ziende wat menschen die geenszins tot de deskundigen behoorden, konden medebrengen, meende, dat de ware rijkdom der (diptera-)natuur eerst goed aan het licht zou komen als te eeniger tijd naar die streken een dipteroloog erop uittrok om te verzamelen en te studeeren. Het is er nooit van gekomen, en in onzen tijd denkt men weer anders over deze dingen, nu tweevleugelige vliegtuigen, die trouwens meer in het oog vallen dan muggen, naar onze Oost stuiven en er overheen, zelfs tot boven Nieuw Guinea.

Naar Suriname is het echtpaar Bonne-Wepster gegaan uitsluitend voor de muggen en hun onderzoek moest ten bate der hygiëne komen; met een medisch doel gingen zij, niet als entomologen; het boek dat zij maakten is dan ook verschenen als Mededeeling XXI van de „,afdeeling Tropische hygiëne No. 13”, derVereeniging het Koloniaal Instituut te Amsterdam en uitgegeven met den bijstand van de Vereeniging tot bevordering der geneeskundige wetenschappen in Nederlandsch-Indië. In dit boek van 550 bladzijden zijn al de soorten beschreven die de auteurs in Suriname hebben gevonden, honderd drie en dertig soorten, waarvan er 46 
nieuw voor de wetenschap bleken; ook zijn er korte aanteekeningen opgenomen omtrent alle aan de schrijvers bekende soorten van tropisch Amerika, met inbegrip van de Antillen, maar met uitzondering van Mexico, waarschijnlijk omdat men daar niet rustig kan werken. Aan het slot vindt men 84 afbeeldingen van kenmerkende lichaamsdeelen der muggen en details van hunne larven. Maar geen enkele mug is er afgebeeld, ook niet van de 46 nieuwe soorten. Dat deden we in den ouden tijd toch anders! Telkens ontmoet men in de onderschriften der platen het woord $\mathrm{Hy}$ popygium, dat in geen enkel woordenboek is te vinden; of ik, zoo vroeg een vriend, hulp kon vinden bij Venus callipyges, Venus met de mooie billen? Inderdaad was ik nu op weg; van het podium waar de natuurlijke historie en zij alleen wordt beoefend kreeg ik ten antwoord, dat men zulke technische termen niet vertaalt. „Wij hebben er in het Nederlandsch geen woord voor en eene omschrijving als ondergenitaalplaat is ook niet fraai." Stellig niet, maar nu kunnen we ons toch eenigszins oriënteeren.

Sommige muggen zijn overal en vooral in Suriname lastige en gevaarlijke insekten; de steek van deze tweevleugeligen is het begin van vele ziekten. In de Indiën spreekt men gewoonlijk van muskieten, wanneer de steekmuggen worden bedoeld. Mosquito, zoowel Spaansch als Portugeesch, is het verkleinwoord van mosca en beteekent eigenlijk kleine vlieg. Van deze steekmuggen is de Anopheles de meest beruchte, ook in West-Indië; dat is de malaria-mug. En een niet minder gevaarlijke soort is deStegomya fasciata die de gele koorts veroorzaakt. Dan gonst er een Culex-soort die men verdenkt den eenen mensch tot een filariosis-, een anderen tot een elefantiasis-lijder te maken. De Filaria is een draadworm, die in het menschelijk lichaam komt door den steek van Culex-soorten, te Paramaribo bijna uitsluitend van Culex fatigans.

Sedert de ontdekking van de overbrenging van eenige parasitaire ziekten door insekten, is het mogelijk geworden deze ziekten te beperken en zelfs om ze uit te roeien, door de overbrengende insekten te lijf te gaan. Zoo is de gele koorts verdwenen uit alle groote steden van Midden- en Zuid-Amerika en een ieder die iets voelt voor de verbetering van 's menschen gezondheids-toestand zal dit een mooi stuk werk noemen. Wat was nu het begin, waarop diende te worden gelet? Sedert den aanvang van het onderzoek naar het overbrengen van ziekten door insekten, bleek het noodig zoowel voor den onderzoeker als voor den hygiënist, een nauwkeurige kennis te erlangen van den habitus der gevaarlijke of voor 
gevaarlijk gehouden soorten, en van de afwijkingen in struktuur die zij vertoonen bij een vergelijking met andere verwante species. Dit was het begin van de praktische toepassing der verkregen kennis ten bate der gezondheid.

DeAnopheles, zeggen de schrijversvan „Mosquitoes of Surinam”, zijn uitvoerig bestudeerd in bijna alle plaatsen waar malaria een ernstige plaag is. Hun eigen ondervinding in Suriname, waar filariasis zeer gewoon mag heeten, heeft hen overtuigd, dat een grondige kennis der Culex-soorten, der larven en de broedplaatsen uitermate bevorderlijk is aan een goede uitkomst bij de bestrijding dezer ziekte. Verzameld hebben de schrijvers zelven zoowel aan de kust als in het binnenland, en zij stellen zich verantwoordelijk voor de opgaven omtrent broedplaatsen, voor het verband tusschen larve en imago (het volwassen dier) en voor de vermelding dat een muskietsoort den mensch aanvalt.

Voor iemand die niet bezig is zich te verdiepen in deze zelfde studie, is het boek gewoon onleesbaar. Maar hier en daar ligt er een enkel stukje dat genietbaar is ook voor den gewonen mensch. Hier zijn eenige regels uit een algemeene beschouwing van het genus Anopheles. „De larven worden hoogst zelden gevonden in kunstmatige waterbekkens (artificial containers of water; bedoeld worden stukken van flesschen, ledige blikken, enz.); de meeste soorten broeden in het water van den bodem, dat in den regel een overvloed van plantengroei heeft; maar noodzakelijk is dit laatste niet. Eenige soorten broeden in de gaten van boomen en in Bromeliaceae. De volwassen exemplaren zijn meerendeels nachtdieren, maar velen vallen ook overdag aan. Eenige soorten zijn bepaald bosch-muskieten, anderen verkiezen de huizen, zoo sterk, dat zij erin blijven gedurende opeenvolgende dagen en nachten. $\mathrm{Zij}$ vallen plotseling aan, zonder aarzelen „before they bite” (voor deze insekten is to sting beter). $\mathrm{Zij}$ zijn zeer dun en slank en in rust liggen proboscis, thorax en abdomen, hoofd, borst en achterlijf, in één lijn, vallen den onervaren waarnemer weinig op; vandaar dat men dikwijls hoort van malaria-gevallen in streken waar de lijders zeggen geen muskieten te hebben gezien" (bl. 496). Met het verzamelen der soorten die in 's menschen nabijheid komen is men er niet af, want dan zouden alleen de vrouwelijke exemplaren worden bewaard; het klinkt ongracieus, maar alleen de vrouwtjes steken. Bij lastige geslachten is het, ook met behulp van museum-materiaal, bezwaarlijk de soorten te determineeren. Daar is b.v. de Culex fatigans, aan wie de lezer reeds is voorgesteld: deze uit een oogpunt van hygiëne zeer belangrijke muskiet is niet met zeker- 
heid te herkennen alleen uit vrouwelijke exemplaren. Opzoeken van de broedplaatsen is noodzakelijk; voor de classificatie zijn de larven veel waard; en de huid van de larve die terugblijft bij de verpopping, en al de larven-eigenaardigheden toont, kan gemakkelijk worden bewaard; heeft men die huid voldoende bekeken terwijl zij nog in het water lag, dan kan men ze laten drogen en in canada-balsem bewaren. Zoo worden we rondgeleid in de keuken van het bedrijf.

In een land als Suriname, waar alle menschelijke ziekten waarvan een mug de oorzaak is zoowel nog vóórkomen als vroeger vóórkwamen, is het volstrekt noodig de lokale muskietenfauna goed te kennen. Op de bauxiet-onderneming Moengo is gebleken wat ten opzichte van Culex fatigans valt te bereiken. Te Paramaribo is deze soort zeer gemeen, in het woud ziet men haar nooit. Soorten die sterk op deze soort gelijken kunnen dadelijk worden afgezonderd na onderzoek van larve en hypopygium.

We moeten even terugkomen op de mededeeling, dat de larven van het genus Anopheles hoogst zelden worden gevonden in het water dat potscherven of ledige blikken hebben opgevangen. In de bespreking van de Stegomyia zeggen de schrijvers, dat ten onrechte veel gewicht wordt gehecht aan kleine hoeveelheden water in de bakjes, waarin, tegen de aanvallen van termieten de voeten van meubels worden gezet; scherven van aardewerk en van glas waarin het water blijft staan, zij zijn volgens de Bonne's „of very little importance". Deze bewering klopt niet met hetgeen „men” daarvan denkt. Een dezer "men” heeft in de N. Rott. Ct. van 8 Maart 1926, Av.bl. A, geprotesteerd en gevraagd op welke waarnemingen deze uitspraak berust. Hij schrijft o.a.: „Waar zeer vele deskundigen op het gebied der malaria juist steeds op het gevaar van deze kleine hoeveelheden water wijzen en ook de in Afrika zeer bekende autoriteit dr. Park Ross het gevaar hiervan wel degelijk inziet, klinkt het verwonderlijk een tegenovergestelde meening door ter zake deskundigen te hooren verkondigen. Persoonlijke waarnemingen in Oost-Afrika hebben mij ervan overtuigd, dat juist de blikjes, scherven, enz. die om bijna iedere woning in de tropen in groote hoeveelheden worden aangetroffen, ware broedplaatsen van muskieten zijn. Opzettelijk daartoe geplaatste bakjes met water bleken na korten tijd te wemelen van muskietenlarven. Tevens is mij en anderen gebleken, dat in de holten der bladscheden van maïs- en andere planten dikwijls voldoende dauw of regenwater aanwezig is om deze holten tot geliefde broedplaatsen van muskieten te maken. Maïs- en suikerrietvelden kun- 
nen, terwijl er op den bodem geen water wordt aangetroffen, belangrijke muskieten-centra zijn."

Misschien is het volgende over C. fatigans een antwoord op de vraag: ,.... this species is very abundant in the capital of the colony, Paramaribo. C. fatigans prefers foul, dirty water for its breeding place, e.g. pools in the back yards of the houses, where water from kitchens collects, pails containing dirty water and all kinds of refuse, privies, sewers and cesspools. This makes it essentially a town and village mosquito, because there the breeding conditions are most favorable. Any mosquito found away from human habitations is probably not Culex fatigans, especially when it is bred from clear water. When only females are found and there is no doubt as to its identity, it will be very easy in case of C. fatigans to make them deposit their eggs and rear the larvae, which are easy to recognize" (bl. 224/5).

En verder: „This kind of breeding place (i. e. privies, septic tanks, kitchen pools, etc) needs a rigorous control, one neglected privy or kitchen pool can breed thousands of Culex fatigans in a few cubic feet of water. Rainwater barrels also contain a certain number of fatigans larvae, especially when they are old and dirty but the larval density of a kitchen-pool is never reached here. Galvanised iron tanks with clear water are still less preferred. The salted-meat barrel, filled with dirty water, which is such a conspicuous thing in many parts of the West Indies, is another example of an ideal breeding place, etc" (bl. 225).

Hieruit blijkt o.a., dat „maiis- en suikerrietvelden” vermoedelijk nooit centra zijn van zwermen muskieten die Culex fatigans heeten. „In the woods away from human habitation this species is never met with. There are several species of non-domestic mosquitoes, which closely ressemble it." De fatigans is een huisdier in den niet-letterlijken zin.

De nieuwe soorten die de heer en mevrouw Bonne-Wepster vonden, schonken zij aan het Instituut voor tropische hygiëne te Amsterdam en aan het U. S. National Museum te Washington. Want ook daar hebben zij de collecties bestudeerd, o.a. het materiaal dat heeft gediend voor de samenstelling van de Carnegiemonografie over dit onderwerp.

Nadat het bovenstaande was geschreven, kwam mij in handen de Januari-aflevering van „Congo, revue générale de la Colo- 
nie belge", met een opstel van J. Schwetz, getiteld $\mathrm{N}$ ot e s u r la future lutte antimalarienne in Elisab e thvi le, „la brillante capitale du Katanga, avec ses belles avenues, ses nombreuses autos et son chic ultra-moderne". Maar vuil! En hier zijn we midden in het vraagstuk door den heer Schwetz bekeken.

Groote hoeveelheden muskieten zijn er in deze plaats, behoorende tot geslachten Culex, Stegomyia, Anopheles en andere. De soorten van laatstgenoemd geslacht zijn „des moustiques domestiques par excellence”. In de lijst van „Mosquitoes of Surinam” ontbreken A. costalis en funestus, „connues comme transmetteuses du paludisme" (moeraskoorts). Blijkbaar Afrikaansche soorten die in Amerika niet vóórkomen. De meest gewone Culex is de C. duttoni, evenmin door Bonne genoemd. De Anopheles-soorten „aiment l'eau claire et fra che", maar de gewoonten van muskieten en larven zijn in het artikel, waar van verschillende soorten sprake is, geenszins scherp onderscheiden, De redeneeringen dobberen op het water en het is moeilijk te raden waar zij zullen landen.

De schrijver onderscheidt wel eenige soorten broedplaatsen, "g tes habituels à larves de moustiques": de scherven en ledige blikjes; de greppels, grachten en slooten; de goten die men in den grond groef bij huizen in aanbouw; de moestuinen en aanplantingen; de woeste gronden met hun talrijke beekjes.

"Je propose donc, en résumé, de commencer par la création d'un service d'hygiène autonome et de mettre à la tête de ce service un médecin compétent et énergique." Dat kan in geen geval kwaad. Des schrijvers „études morphologiques et biologiques des moustiques de la capitale du Katanga" zijn nog niet afgeloopen, en zullen later worden openbaar gemaakt.

Joh. F. SNelleman. 